\title{
Assessing the Rigidity of the River Continuum Concept to Fish Species in a Fluvially Dominated Southern African Coastal System
}

Festus P. Nashima ( $\square$ fnashima@unam.na )

University of Namibia

Nadine A. Strydom

Nelson Mandela University

Stephen J. Lamberth

Nelson Mandela University

\section{Research Article}

Keywords: Estuary, fish species, river-estuary continuum, salinity gradient

Posted Date: August 11th, 2021

DOI: https://doi.org/10.21203/rs.3.rs-778961/v1

License: (c) (i) This work is licensed under a Creative Commons Attribution 4.0 International License.

Read Full License 


\section{Abstract}

A continuous gradient of physical and biological processes exists within a river system from headwaters to mouth, according to the River Continuum Concept. In this study, the River Continuum Concept was used to compare patterns in fish assemblages and diversity trends to Remane predictions. The findings show that species diversity is low near the estuary's mouth and increases upstream. While the presence of several marine and estuarine species increased species diversity upstream in the river due to the dominance of freshwater fishes, it decreased downstream due to the presence of several marine and estuarine species. These patterns are consistent with the biogeographical trend of decreasing species richness along the South African coast from east to west. Based on the findings of this study, the River Continuum Concept ignores plasticity, which is evident in species that use transitional waters. As a result, the concept is insufficiently valid for the Orange River Estuarine Continuum, and a new concept known as the "River-Estuarine Continuum" has been proposed.

\section{Introduction}

Some of the ecological models used to describe the longitudinal distribution along estuarine and riverine reaches are the River Continuum Concept (RCC) and the Remane model, respectively. The River Continuum Concept describes changes in biological processes that occur along the course of rivers from their headwaters to their mouths while remaining connected throughout (Vannote et al. 1980). Whereas, the Remane model describes how species diversity changes along the transitional salinity gradient (Attrill, 2002; Whitfield et al. 2012). As a result, the River Continuum Concept was adopted to examine its usefulness in predicting the behaviour of fishes in a fluvially dominated southern African river system.

Changes in salinity conditions along the river system drive changes in communities (Isom 1986) by controlling the distribution of species along a habitat continuum (Barnard 1998; Barletta et al. 2005). Fishes that utilize an estuarine environment exhibit a wide range of environmental tolerances and preferences as a result of adaptation to these highly variable environments (Kennish 1990). However, several fish species may be subject to physiological limitations resulting in temporal changes in species composition, distribution, and abundance (Tremain and Adams 1995; Harrison and Whitfield 2006; Whitfield et al. 2012).

The river-continuum concept combined various ecological changes along the river to create a unified description from the headwaters to the mouth. The concept attempts to categorize species but ignores species plasticity, particularly for fish species that live in transitional waters. The Orange River Estuary (ORE) is home to a variety of freshwater, marine, and estuarine species (Lamberth 2003; Næsje et al. 2007; Ramollo 2011). As a result, ORE provides a perfect system to test the rigidity of the river-continuum concept. Therefore, this study aims to 1) assess how freshwater, estuarine and marine fish species are structured along the river-estuarine system, and 2) examine the rigidity of river continuum predictions in the Orange River system. 


\subsection{Overview of Remane predictions}

Adolf Remane created a diagram in 1934 to depict changes in benthic invertebrate diversity along a salinity gradient within the Baltic system which is a brackish sea (Attrill 2002). Vannote et al. (1980) expanded the diagram by including fishes in the original diagram, in an attempt to describe structures and synthesize a set of general hypotheses about communities along a river system. However, the diagram has received criticism due to its several limitations (Hedgpeth 1967; Odum 1988; Barnes 1989; Hudson 1990; Attrill 2002; Whitfield et al. 2012). Despite the limitations, the model has been recognized as a textbook model in stream ecology (Cummins et al. 1984; Attrill 2002; Statzner and Higler 2008). Based on the model, the diversity of freshwater taxa declines rapidly at salinities ranging from 0.5 to 5 , with the minimum species richness occurring at 5 to 7 . At a salinity of 6 , estuarine species predominate, whereas, at a salinity of 7, marine species predominate (Remane 1934).

Over the years, several scholars have been modifying the diagram to present a generalized model for describing diversity trends in estuaries. Hedgpeth (1967), expanded the diagram to include the entire salinity spectrum. Hudson (1990) changed the shape of the original model by depicting the freshwater biota as having lower species diversity than the marine biota, as well as extending the presence of estuarine species beyond the 20 salinity limit. Whitfield et al. (2012) presented a combined revised model that demonstrates the connection between salinity and faunal trends in estuaries. Besides the revised model, its applicability to the Orange River Estuary, particularly given that it is a large fluvially dominated estuarine system, is unknown.

\section{Material And Methods \\ 2.1 Study area}

The Orange River flows over 2,300 km from its origin in the highlands of Lesotho downstream into the Atlantic Ocean (Næsje et al. 2007; Ramollo 2011). At the mouth, there is an estuary that forms the border

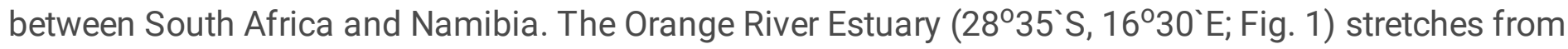
the mouth to about $10 \mathrm{~km}$ upstream (Williams 1986). Its catchment area covers $549,000 \mathrm{~km}^{2}$ and drains approximately $60 \%$ of South Africa's land area, while the remainder falls within Botswana (11\%), Namibia (25\%), and Lesotho (4\%) (Mohamed 2003).

The Orange River Catchment falls within the summer rainfall zone whereas the Orange River Estuary is located in the arid and cold temperate climate region (Allanson and Baird 2009) and falls within a winter rainfall zone, where infrequent rainfalls and averages about $50 \mathrm{~mm}$ per year (van der Merwe 1983; Næsje et al. 2007). As a result, high-flow downstream occurs during the summer months rather than during the winter rainfall season (Næsje et al. 2007).

\subsection{Field sampling}


Fieldwork was carried out during the typical high-flow (December-March) and low-flow (August-October) seasons (van Langenhove et al. 1998). Within a 15-year period, sampling was carried out in eight different years $(2004,2005,2012,2013,2015,2016,2017$ and 2018). Two sampling trips were conducted biannually for all years except 2012, 2013, and 2016 during the high-flow period, and also in 2017 during the low-flow period. During any of the sampling trips, however, no high-high flow was observed. This was due to river system regulation upstream by the Gariep and Vanderkloof dams which significantly reduced the amount of water flowing downstream to the estuary (Bremner et al. 1990; Anderson et al. 2003). Throughout this study, the Orange River Estuary remained open (2004-2018).

A beach-seine ( $30 \times 2 \times 10 \mathrm{~m})$ was used for sampling at 18 sites from the mouth of the estuary to $35 \mathrm{~km}$ upstream (Fig. 1). The mesh size of the net is $10 \mathrm{~mm}$ in the centre, including a cod-end (bag), and $10 \mathrm{~m}$ of $15 \mathrm{~mm}$ stretched mesh size in each of the wings. The distances between sites vary greatly, and they were chosen to reflect a progression from marine to estuarine to freshwater influences as well as accessibility to the riverbed. Fish caught were identified to species level (Smith and Heemstra 1986; Skelton 2001), measured and counted at each site. After recording fishes were released alive into the water where possible. All applicable guidelines for the care, collection and use of animals were followed in accordance with the ethical standards of Nelson Mandela University (NMU, South Africa). Specifically, the ethics clearance was granted by the Research Ethics Committee (Animal), Nelson Mandela University. The ethics clearance reference number is A18-SCl-ZOO-002.

The number of fish species that were collected one haul at each site was recorded. Also, salinity (expressed as practical salinity units) was measured at each site, from the middle of the water column, using a Yellow Spring Instrument v6920/EXO 1 multi-parameter probe. The river-estuarine area was divided into salinity zones based on an adaptation of the Venice system of South African salinity zones in estuaries (freshwater: 0-0.49 PSU; oligohaline: 0.5-4.9 PSU; mesohaline: 5.0-17.9 PSU; polyhaline: 18.0-29.9 PSU; euryhaline: 30.0-35.9 PSU; and hypersaline: $\geq 36$ PSU) (Strydom et al. 2003).

Moreover, fishes recorded were grouped into estuarine associations following Potter et al. (2015). Many researchers who research in most southern African estuaries use this approach. The marine category is divided into three guilds (marine straggler, marine estuarine-opportunist, and marine estuarinedependent), the estuarine category is divided into four guilds (solely estuarine, estuarine \& marine, estuarine \& freshwater, and estuarine migrant), the diadromous category is divided into five guilds (anadromous, semi-anadromous, catadromous, semi-catadromous and amphidromous), freshwater category consists of two guilds, namely the freshwater straggler and freshwater estuarine-opportunistic (Potter et al. 2015).

\subsection{Data analyses}

The diversity indices including Shannon-Wiener diversity $(H)$ and the number of species (S)) were calculated using PRIMER v6 statistical software package among seasons, years, and sites (Clarke and Warwick 1994). Moreover, salinity levels measured at each site were categorized into salinity zones based on an adaptation of the Venice system (Strydom et al. 2003). 
The assumptions of normality and homogeneity of variance were tested using a normal probability plot and Levene's Test. All diversity indices data revealed violation of both normality and homogeneity of variances. Mann-Whitney U-test (Zar 1999) was used to test whether diversity indices ( $H^{\prime}$ and S) differed between high-flow and low-flow season. Kruskal-Wallis tests were performed separately on species diversity indices to test for differences between years and salinity zones. Stacked area diagrams were created in Microsoft Excel 2013 to show the distribution of estuarine associations based on Potter et al. (2015), as well as a salinity continuum based on the revised Venice system for salinity zone classification (Strydom et al. 2003). The significance level for all tests was set at 0.05 alpha.

\section{Results}

\subsection{Fish species composition}

Over the eight-year study period, a total of 26086 fish were caught, representing 30 species. According to the previous study by Nashima et al. (2021), the majority of fish species belongs to the freshwater category (47\%) based on estuarine associations, with 11 freshwater stragglers and three freshwater estuarine-opportunist's species. The estuarine category (20\%) included one solely estuarine species, five estuarine and marine species, and no estuarine and freshwater or estuarine migrant species. The marine category (33\%) included four marine stragglers, three marine estuarine-opportunists, and three marine estuarine-dependents.

\subsection{Seasonal and spatial trends in species diversity}

The number of species $(S)$ and Shannon-Wiener diversity $(H)$ differed significantly between the high-flow and low-flow seasons (S: Mann-Whitney U-test, $\mathrm{z}=-6.88, \mathrm{p}<0.001 ; H$ : Mann-Whitney U-test, $\mathrm{z}=-5.01, \mathrm{p}<$ 0.001 ). Both diversity indices depicted high values during the high-flow season (Table 1). Species

diversity indices showed significant differences among salinity zones but not years. Overall, both showed an increasing trend upstream into freshwater (Fig. 2; Table 1). 
Table 1

The diversity indices (S and $H$ ) of fish assemblages recorded in different salinity zones during the high-flow and low-flow season in the Orange River Estuary

Continuum during 2004-2018.

\begin{tabular}{|lll|}
\hline & No. of species $(\mathbf{S})$ & Shannon-Wiener diversity $(\boldsymbol{H})$ \\
\hline Salinity Zone (Range) & & \\
\hline Fresh $(0-0.49)$ & 24 & 1.05 \\
\hline Oligohaline (0.5-4.9) & 23 & 0.41 \\
\hline Mesohaline (5.0-17.9) & 14 & 0.13 \\
\hline Polyhaline (18.0-29.9) & 10 & 0.05 \\
\hline Euhaline (30.0-35.9) & 10 & 0.14 \\
\hline Season & & \\
\hline High-flow $(n=80)$ & 28 & 0.60 \\
\hline Low-flow $(n=121)$ & 27 & 0.27 \\
\hline Entire study area & 30 & 3.56 \\
\hline
\end{tabular}

\subsection{Estuarine species association along the river-estuarine continuum}

This study recorded a salinity range of 0.1 to 34.9. The dominance of freshwater species in freshwater during the high-flow and low-flow seasons was depicted by a rapid decline toward oligohaline and then more saline water (Fig. 2). Moreover, the majority of freshwater species were restricted to salinities below mesohaline conditions (5.0-17.9). During the high-flow season, Tilapia sparrmanii was the only freshwater species found in polyhaline water (2005 and 2007). During the low-flow season, no freshwater taxa were recorded in either polyhaline (18.0-29.9) or euhaline (30.0-35.9) (Table 2). 
Table 2

Species checklist of presence (+) and absence ( ) of fish species in varying salinity zones recorded in the

Orange River Estuary during 2004-2018, based on estuarine usage functional guild. $\mathrm{F}=$ Fresh, 0 = Oligohaline, $\mathrm{M}=$ Mesohaline, $\mathrm{P}=$ Polyhaline, $\mathrm{E}=$ Euhaline.

\begin{tabular}{|c|c|c|c|c|c|c|c|c|c|c|c|}
\hline \multirow[b]{2}{*}{ Scientific name } & \multirow[b]{2}{*}{ EUFG } & \multicolumn{5}{|c|}{ High-flow season } & \multicolumn{5}{|c|}{ Low-flow season } \\
\hline & & $\mathbf{F}$ & 0 & $M$ & $\mathbf{P}$ & $\mathbf{E}$ & $\mathbf{F}$ & 0 & M & $\mathbf{P}$ & $\mathrm{E}$ \\
\hline Gilchristella aestuaria & Solely estuarine & + & + & + & + & + & + & + & + & + & + \\
\hline Caffrogobius nudiceps & Estuarine \& marine & + & + & + & + & & & & + & & + \\
\hline Caffrogobius saldanha & Estuarine \& marine & + & + & + & + & + & & + & + & + & + \\
\hline Clinus superciliosus & Estuarine \& marine & & + & & & & & & + & + & + \\
\hline Atherina breviceps & Estuarine \& marine & + & + & + & + & + & & + & + & + & + \\
\hline Syngnathus temminckii & Estuarine \& marine & + & + & + & & & + & & & & + \\
\hline Chelon richardsonii & $\begin{array}{l}\text { Marine-estuarine- } \\
\text { opportunist }\end{array}$ & + & + & + & + & + & + & + & + & + & + \\
\hline Lichia amia & $\begin{array}{l}\text { Marine-estuarine } \\
\text { dependent }\end{array}$ & & + & & & & & & & & \\
\hline Pomatomus saltatrix & $\begin{array}{l}\text { Marine-estuarine- } \\
\text { opportunist }\end{array}$ & & + & & + & & & + & & & \\
\hline Mugil cephalus & $\begin{array}{l}\text { Marine-estuarine } \\
\text { dependent }\end{array}$ & & + & & & & + & & & & \\
\hline $\begin{array}{l}\text { Rhabdosargus } \\
\text { globiceps }\end{array}$ & $\begin{array}{l}\text { Marine-estuarine- } \\
\text { opportunist }\end{array}$ & & & & + & & & & & & + \\
\hline $\begin{array}{l}\text { Lithognathus } \\
\text { lithognathus }\end{array}$ & $\begin{array}{l}\text { Marine-estuarine } \\
\text { dependent }\end{array}$ & & & & & & + & & & & \\
\hline Lithognathus aureti & Marine straggler & & + & & & & & & & & \\
\hline $\begin{array}{l}\text { Chelidonichthys } \\
\text { capensis }\end{array}$ & Marine straggler & & + & & + & & & + & + & & + \\
\hline Cynoglossus capensis & Marine straggler & & & & & & & & & & + \\
\hline $\begin{array}{l}\text { Austroglossus } \\
\text { microlepis }\end{array}$ & Marine straggler & & + & & & & & & & & \\
\hline Labeobarbus aeneus & Freshwater straggler & + & + & + & & & + & + & + & & \\
\hline $\begin{array}{l}\text { Oreochromis } \\
\text { mossambicus }\end{array}$ & $\begin{array}{l}\text { Freshwater estuarine- } \\
\text { opportunist }\end{array}$ & + & + & + & & & + & + & & & \\
\hline Tilapia sparrmanii & Freshwater straggler & + & + & & + & & + & & + & & \\
\hline Mesobola brevianalis & Freshwater straggler & + & & & & & + & + & + & & \\
\hline
\end{tabular}




\begin{tabular}{|llll|}
\hline $\begin{array}{l}\text { Pseudocrenilabrus } \\
\text { philander }\end{array}$ & $\begin{array}{l}\text { Freshwater estuarine- } \\
\text { opportunist }\end{array}$ & $+\quad+\quad+$ Low-flow season \\
\hline $\begin{array}{l}\text { Labeobarbus } \\
\text { kimberleyensis }\end{array}$ & Freshwater straggler & + & + \\
\hline Labeo umbratus & Freshwater straggler & + & + \\
Clarias gariepinus & $\begin{array}{l}\text { Freshwater estuarine- } \\
\text { opportunist }\end{array}$ & + & + \\
Cyprinus carpio & Freshwater straggler & + & + \\
\hline Barbus trimaculatus & Freshwater straggler & + & + \\
\hline Barbus hospes & Freshwater straggler & + & + \\
\hline Barbus paludinosus & Freshwater straggler & + & + \\
\hline Labeo capensis & Freshwater straggler & + & + \\
\hline Gambusia affinnis & Freshwater straggler & + & + \\
\hline
\end{tabular}

The highest species diversity values in the marine category were recorded in oligohaline waters during a high-flow season (Table 1), with three marine estuarine-opportunists (C. richardsonii, Pomatomus saltatrix, and Rhabdosargus globiceps), three marine stragglers (Lithognathus aureti, Austroglossus macrolepis, and Chelidonichthys capensis), and two marine estuarine-dependent (Lichia amia and Mugil cephalus) species. The absence of marine estuarine-dependent species ( $M$. cephalus and Lithognathus lithognathus) in salinities above oligohaline was notable (Table 2).

Chelon richardsonii and $M$. cephalus were the only two marine species with unrestricted distribution into freshwater reaches (Table 2). Other marine species, such as L. amia, Chelidonichthys capensis, L. aureti, and Pomatomus saltatrix, were only found up to the oligohaline zone (Table 2). Despite this, all other species, regardless of origin, were underrepresented in the Orange River Estuary in terms of percentage occurrences, except for $C$. richardsonii (Nashima et al. 2021).

Freshwater and all other salinity zones (i.e. oligohaline, mesohaline, polyhaline and euhaline) had different numbers of freshwater species, according to the Kruskal-Wallis pairwise test. Whilst for marine and estuarine categories, there were no differences in the number of species among salinity zones (Fig. 3). Gilchristella aestuaria, a solely estuarine species, and C. richardsonii, a marine estuarineopportunist, were widely distributed across salinity zones. Overall, the number of species recorded in the ORE, showed the dominance of freshwater species in fresh and oligohaline while estuarine species dominate polyhaline and euhaline waters (Fig. 3).

\section{Discussion}


The Remane model, derived from the Baltic region, has been consistently portrayed as the textbook model for estuarine diversity trends (Attrill 2002). However, the model was criticized for having too many limitations for general use in estuaries. This model has been extended and modified over the years to provide an alternative generalized model for describing diversity trends in estuaries (e.g. Hedgpeth 1967; Odum 1988; Barnes 1989; Hudson 1990; Attrill 2002). Whitfield et al. (2012) presented a revised review, believed as an appropriate model for describing faunal biodiversity patterns along a salinity gradient in estuaries. The revised model shows how the relative proportions of freshwater, estuarine and marine fauna change along a salinity gradient (Whitfield et al. 2012).

Whitfield et al. (2012) presented the following features in their revised model:

1) Freshwater taxa have fewer species than marine taxa in the same estuary;

2) The vast majority of freshwater species are restricted to freshwater habitats, with only a few taxa extending into mesohaline, polyhaline, and euhaline zones;

3) Marine taxa predominate in estuarine waters that are mesohaline, polyhaline, or hyperhaline.

4) Although in small numbers, marine species can be found in oligohaline estuaries and even freshwaters.

5) Estuarine species are more diverse in mesohaline and polyhaline waters, but they can also be found in oligohaline, euhaline, and hyperhaline waters.

6) A reduction in species diversity from high saline to low saline waters. Also, diversity starts to decline above a salinity of about 40 .

In contrast to the ORE, the system is distinct in that it has high productivity but low diversity in comparison to other estuaries in the cool-temperate biogeographical region. Furthermore, the system has a limited number of estuarine species (Brown 1959). Low species diversity corresponded to the South African coast's biogeographical trend of decreasing species richness from east to west (Lamberth 2003). The ORE is dominated by freshwater biota rather than marine and estuarine species, with species diversity declining along a salinity continuum. Based on the estuarine association categories the distribution of freshwater, estuarine and marine species differed significantly among salinity zones but not guilds.

The solely estuarine $G$. aestuaria was present among all salinity zones along the river-estuarine continuum. Freshwater stragglers dominated the freshwater zone and progressively declined from the oligohaline water toward more saline water up to a salinity of 20.70 (polyhaline), while estuarine species progressed into the euhaline water. Three $T$. sparrmanii were recorded in mesohaline/polyhaline water during the high-flow season. As expected, Tilapias are known as tolerant of higher salinity stress (Popma and Lovshin 1994). Three species of freshwater estuarine-opportunists Clarias gariepinus, Pseudocrenilabrus philander and Oreochromis mossambicus were present in fresh and oligohaline but 
the latter species penetrated further into mesohaline but not in the polyhaline and euhaline reaches of the Orange River Estuary. Mozambique tilapia O. mossambicus has been recorded in salinities ranging from 0-100 (Whitfield 1998; Næsje et al. 2007), despite its highly euryhaline characteristics, it was absent in polyhaline and euhaline reaches of the Orange River Estuary. Oreochromis mossambicus may be avoiding estuarine reaches associated with an open mouth.

Estuarine \& marine species were the second dominant species (i.e. Syngnathus temminckii, Caffrogobius nudiceps, Caffrogobius saldanha, Clinus superciliosus and Atherina breviceps) in freshwater and declined gradually toward polyhaline (10.0-29.9) and thereafter it increased into euhaline water. The presence of marine estuarine-dependent species M. cephalus, L. lithognathus and L. amia in fresh and oligohaline water are not surprising as they are known to penetrate the freshwater (especially if trapped) for one or two years and mature before moving out to sea to breed (Lamberth 2003; Næsje et al. 2007). The presence of piscivorous predators such as $L$. amia and $P$. saltatrix can indicate feeding usage of the ORE by the two species. Overall, the low number of marine fish species diversity in the Orange River Estuary may be related to the high dominance of riverine influences throughout the estuary. However, $C$. richardsonii is dominant throughout the ORE.

This study concludes that the ideas presented in both the Remane (Remane 1934) and the revised model (Whitfield et al. 2012) do not accurately reflect the biodiversity situation for ORE, taking into account the plasticity observed in species that use the river-estuarine system. As a result, this study developed a new concept suitable for the River-Estuarine Continuum (REC) in the ORE. The following features are included in the proposed new REC:

1) Both marine and estuarine species are present in all salinity zones (i.e. fresh, oligohaline, mesohaline, polyhaline, and euhaline waters);

2) Freshwater species outnumber marine and estuarine species in terms of taxa;

3) The majority of freshwater species are confined to freshwater, oligohaline, and mesohaline waters, with only a few taxa extending into polyhaline waters. No freshwater species were found in euhaline waters;

4) Estuarine species are more diverse in euhaline waters than in freshwater, oligohaline, mesohaline, and polyhaline waters;

5) The ORE is dominated by a single marine species (C. richardsonii).

6) There is a decrease in species diversity as one moves from low to high salinity waters.

In comparison to the original and revised models (Remane 1934; Whitfield et al. 2012), it is clear that fish diversity in the ORE is distinct, as more saline water lacked the substantial amount of marine taxa as hypothesized by pre-existing models. Nonetheless, fish assemblages that utilize the river-estuarine environment, particularly the dominant ones, use a wide salinity range (i.e. plasticity) along the ORE (i.e. 
C. richardsonii and G. aestuaria). Overall, the observed patterns were influenced by the biogeographical trend of decreasing species richness on the South African coast from east to west (Lamberth 2003). Furthermore, differences in species tolerance and preference for changes in salinity along the ORE can dictate the presence of fish species along the river system.

\section{Conclusion}

The Orange River Estuary continues to be ecologically important for a variety of aquatic species, particularly marine and freshwater fish. The findings of this study revealed that the River Continuum Concept's general applicability is insufficient for the ORE due to significant variation in fish diversity and composition along a salinity gradient. As a result of this research, a new river-estuarine concept with new features was proposed. The idea presented in the new concept, however, needs to be tested in other estuarine systems to determine its applicability and whether this trend is unique to the Orange River Estuary.

\section{Declarations}

\section{ACKNOWLEDGEMENTS}

The authors would like to thank Jabu Nhleko, Corne Erasmus, and staff at the South African Department of Environment, Forestry, and Fisheries, as well as Lara van Niekerk of the CSIR, for their assistance during fieldwork in the Orange River and Estuary from 2004 to 2018. Furthermore, the authors would like to thank the Namibian Ministry of Fisheries and Marine Resources and the South African Department of Forestry, Fisheries, and Environment for granting permission to conduct this research. The University of Namibia (UNAM), the Namibia Student Financial Assistance Fund (NSFAF), and the Department of Forestry, Fisheries, and Environment (South Africa), as well as the BENEFIT and BCLME programs, provided financial support for this research.

\section{Funding:}

This study was supported financially by the University of Namibia (UNAM), the Namibia Student Financial Assistance Fund (NSFAF), and the Department of Forestry, Fisheries and Environment (South Africa) and the BENEFIT and BCLME programs.

\section{Conflict of interest:}

The authors declare that they have no conflict of interest.

\section{Availability of data and material:}




\section{Code availability:}

Not applicable

\section{Ethics approval:}

The ethics clearance was granted by the Research Ethics Committee (Animal), Nelson Mandela University. The ethics clearance reference number is A18-SCI-Z00-002.

\section{References}

1. Allanson B, Baird D (eds) (2009) Estuaries of South Africa. In Estuaries of South Africa (p. 340). Cambridge University Press, Cambridge

2. Anderson MD, Kolberg H, Anderso PC, Dini J, Abrahams A (2003) Waterbird populations at the Orange River mouth from 1980-2001: a re-assessment of its Ramsar status. Ostrich, 74:159-172

3. Attrill MJ (2002) A testable linear model for diversity trends in estuaries. J Anim Ecol 71:262-269

4. Barnard KH (1943) Revision of the Indigenous freshwater fishes of the S-W Cape region. Ann S Afr Mus 36:101-262

5. Barletta M, Barletta-Bergan A, Saint-Paul U, Hubold G (2005) The role of salinity in structuring the fish assemblages in a tropical estuary. J Fish Biol 66:45-72

6. Barnes RSK (1989) What, if anything, is a brackish water fauna? Earth Environ Sci Trans 80:235-240

7. Bremner JM, Rogers J, Willis JP (1990) Sedimentological aspects of the 1988 Orange river floods. Trans R Soc 47:217-294

8. Clarke KR, Warwick RM (1994) Change in marine communities: An approach to statistical analysis and interpretation. Plymouth Marine Laboratory, Plymouth

9. Cummins KW, Minshall WG, Sedell JR, Gushing CE, Petersen RC (1984) Stream ecosystem theory. IATAL 22:1818-1827

10. Harrison TD, Whitfield AK (2006) Temperature and salinity as primary determinants influencing the biogeography of fishes in South African estuaries. Estuar Coast Shelf Sci 66:335-345

11. Hudson JD (1990) Salinity from faunal analyses and geochemistry. In: D. E. C. Briggs \& P. R. Crowther (Eds.), Palaeobiology, a synthesis (pp. 406-408). Blackwell Scientific, Oxford

12. Hay CJ, van Zyl BJ, van der Bank FH, Ferreira JT, Steyn GJ (1999) The distribution of freshwater fish in Namibia. Cimbebasia 15:41-63

13. Hedgpeth JW (1967) Ecological aspects of the Laguna Madre, a hypersaline estuary. In G. H. Lauff (Ed.), Estuaries (pp. 408-419). American Association for the Advancement of Science Publication, Washington DC 
14. Isom BG (ed.) (1986) Rationale for Sampling and Interpretation of Ecological Data in the Assessment of Freshwater Ecosystems. A symposium sponsored by ASTM Committee D-19 on Water, Philadelphia, PA. American Society for Testing and Materials

15. Kennish MJ (1990) Ecology of Estuaries (Vol. 2). Boca Raton, Florida: CRC Press, Inc.

16. Lamberth SJ, van Niekerk L, Hutchings K (2008) Comparison of, and the effects of altered freshwater inflow on, fish assemblages of two contrasting South African estuaries: the cool-temperate Olifants and the warm-temperate Breede. Afr J Mar 30:311-336

17. Lamberth SJ (2003) Draft specialist report on the fish of the Orange River Estuary. Orange River Estuary Rapid Ecological Reserve. Final Draft. Unpublished. 12pp

18. Mohamed A (2003) Joint Development Cooperation in International Water Resources. In M. Nakayama (Ed.). International Waters in Southern Africa. United Nations University Press, Tokyo

19. Nashima FP, Strydom NA, Lamberth SJ (2021) Abundance and Diversity of Fish Assemblages Along the River-Estuary Continuum in a Fluvially Dominated Southern African Coastal System. Estuar and Coast 1-16

20. Næsje TF, Hay CJ, Nickanor N, Koekemoer J, Strand R, Thorstad EB (2007) Fish populations, gill net catches and gill net selectivity in the Lower Orange River, Namibia, from 1995 to 2001. NINA Report 231

21. Odum WE (1988) Comparative ecology of tidal freshwater and salt marshes. Annu Rev Ecol Syst 19:147-176

22. Popma TJ, Lovshin LL (1994) Worldwide prospects of commercial production of tilapia. Department of Fisheries and Allied Aquaculture, Auburn University, Alabama. 43pp

23. Potter IC, Tweedley JR, Elliott M, Whitfield AK (2015) The ways in which fish use estuaries: A refinement and expansion of the guild approach. Fish Fish 16:230-239

24. Ramollo PP. (2011) Freshwater fish abundance and distribution in the Orange River South Africa. J Fish. Int 6:13-17

25. Remane A (1934) The brackish water fauna. T Neg Ger Zool Soc 7:34-74

26. Skelton PH, Cambray JA (1981) The freshwater fishes of the middle and lower Orange River. Koedoe 24:51-66

27. Skelton PH (2001) A Complete Guide to the Freshwater Fishes of Southern Africa. Struik Publishers, Pretoria

28. Smith MM, Heemstra PC (1986) Smith's sea fishes. Springer-Verlag, Berlin

29. Statzner B, Higler B (2008) Questions and Comments on the River Continuum Concept. Can J Fish Aquat Sci 42:1038-1044

30. Strydom NA, Whitfield AK, Wooldridge TH (2003) The role of estuarine type in characterizing early stage fish assemblages in warm temperate estuaries, South Africa. Afr Zool 38:29-43

31. Tremain DM, Adams DH (1995) Seasonal variations in species diversity, abundance, and composition of fish communities in the northern Indian River Lagoon, Florida. Bull Mar Sci 57:171- 
192

32. van der Merwe JH (1983) Atlas of SWA/Namibia. University of Pretoria Press, Pretoria

33. van Langenhove G, Amakali M, De Bruine B (1998) Variability of flow regimes in Namibian rivers: natural and human-induced causes. IAHS 252:455-462

34. Vannote RL, Minshall GW, Cummins KW, Sedell JR, Gushing CE (1980) The river continuum concept. Can J Fish Aquat Sci 37:130-137

35. Whitfield AK, Elliott M, Basset A, Blaber SJM, West RJ (2012) Paradigms in estuarine ecology - A review of the Remane diagram with a suggested revised model for estuaries. Estuar Coast Shelf Sci 97:78-90

36. Whitfield AK (1998) Biology and Ecology of Fishes in Southern Africa Estuaries (Vol. 2).

Grahamstown, South Africa: Ichthyological Monographs of the J.L.B. Smith Institute of Ichthyology

37. Williams AJ (1986) Wetland birds at the Orange River mouth and their conservation significance. Bontebok 5:17-23

38. Zar JH (1999) Biostatistical analysis (4th ed.). Prentice-Hall, New Jersey

\section{Figures}

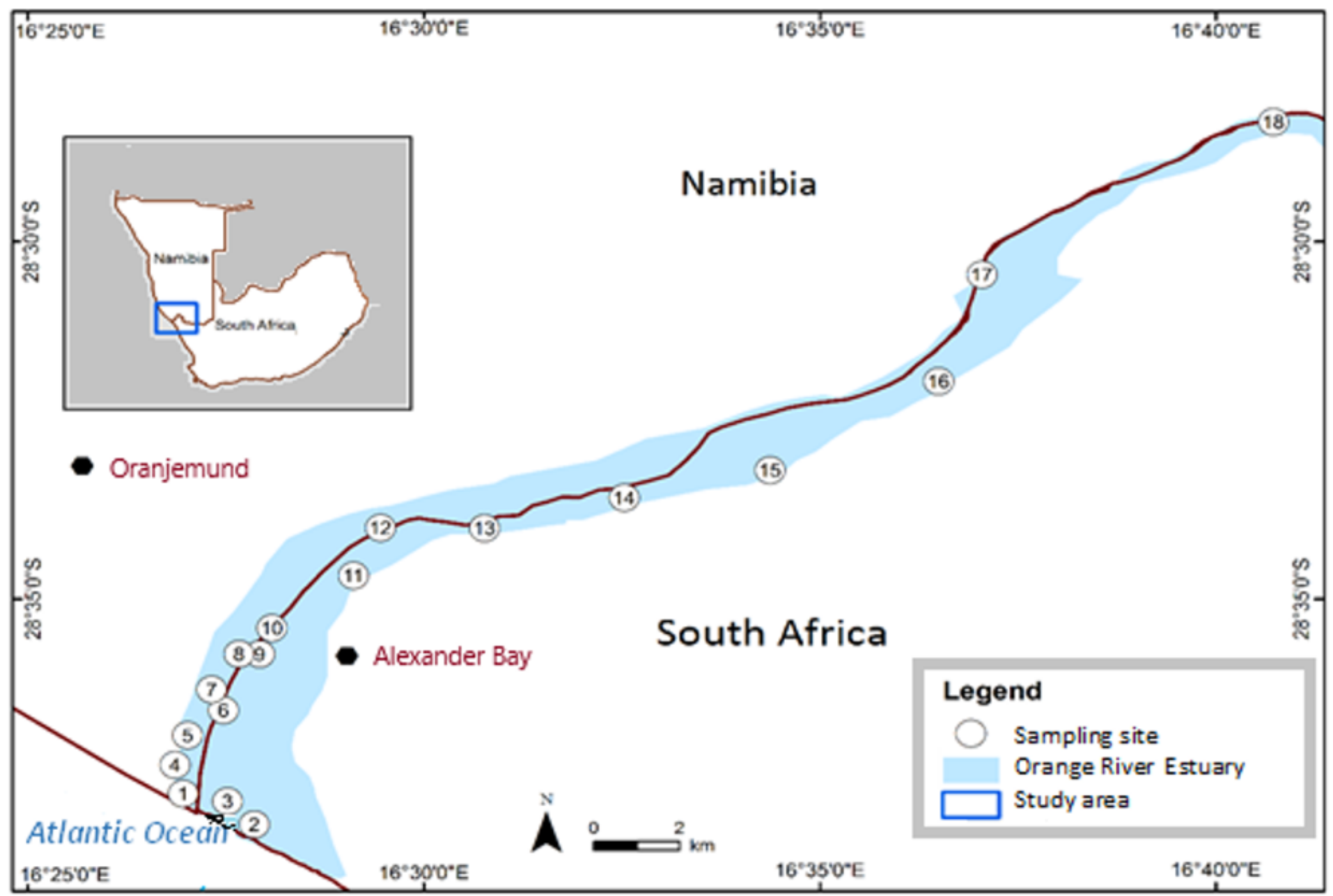


Figure 1

The Orange River Estuary is shown on the map from site 1 to 11 , while the river section is shown from site 12 to 18.

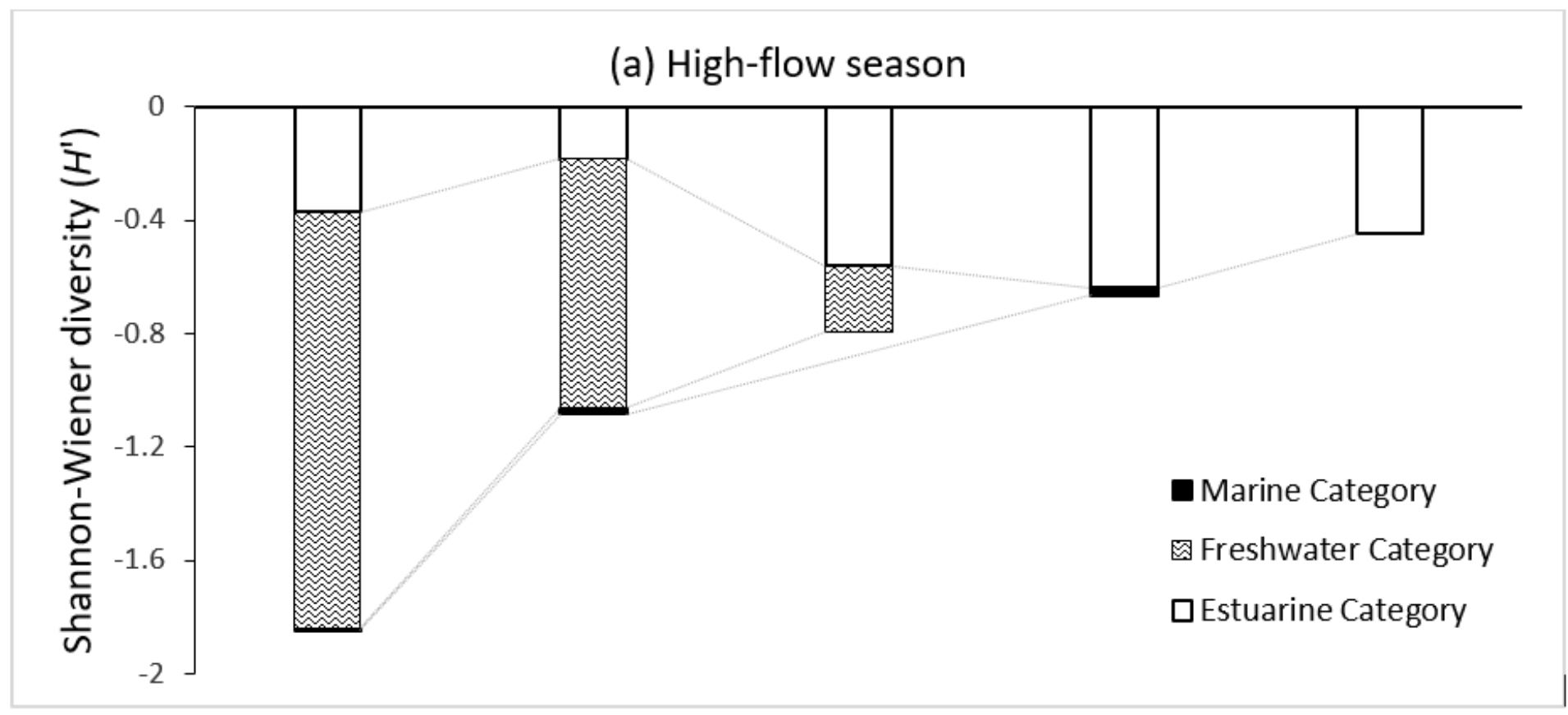

(b) Low-flow season

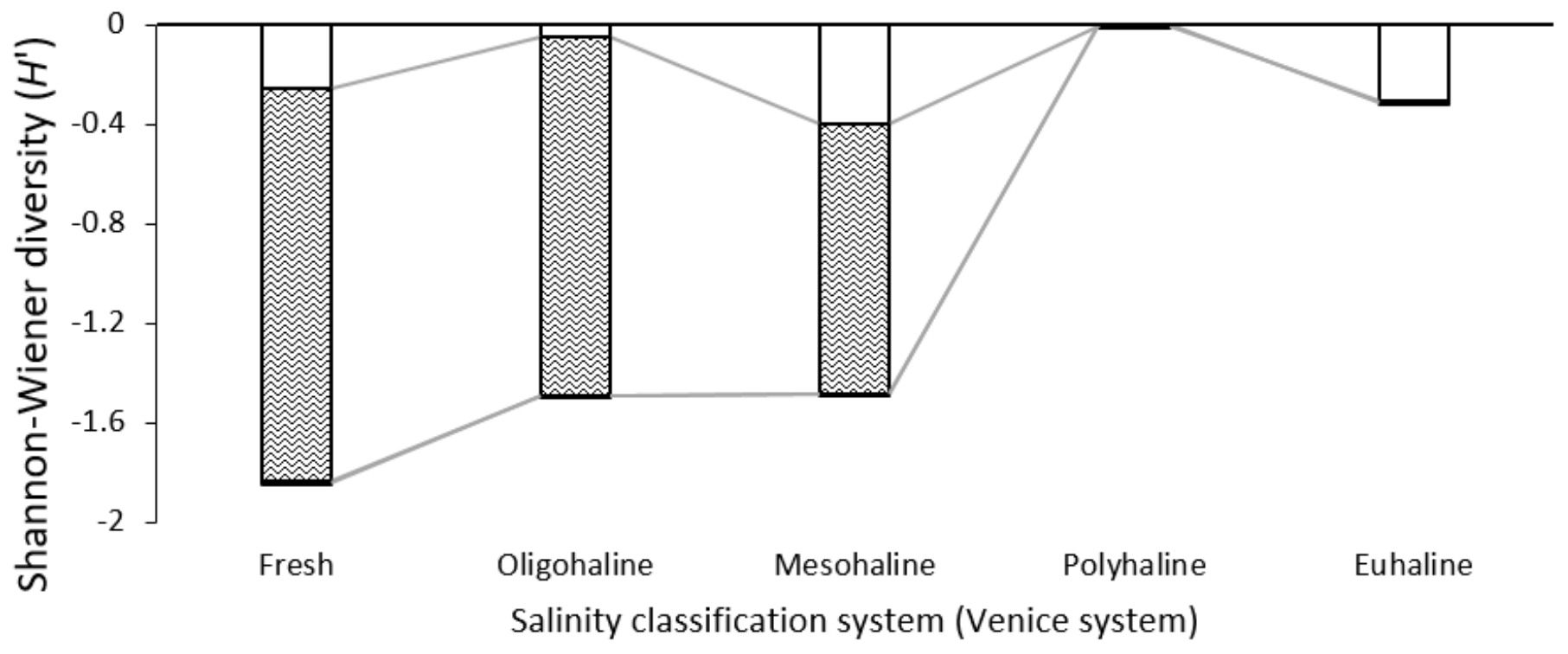

Figure 2

Seasonal changes in estuarine functional grouping covering the salinity continuum from freshwater to euhaline conditions based on an adaptation of the Venice system for the classification of salinity zones (Strydom et al., 2003). 


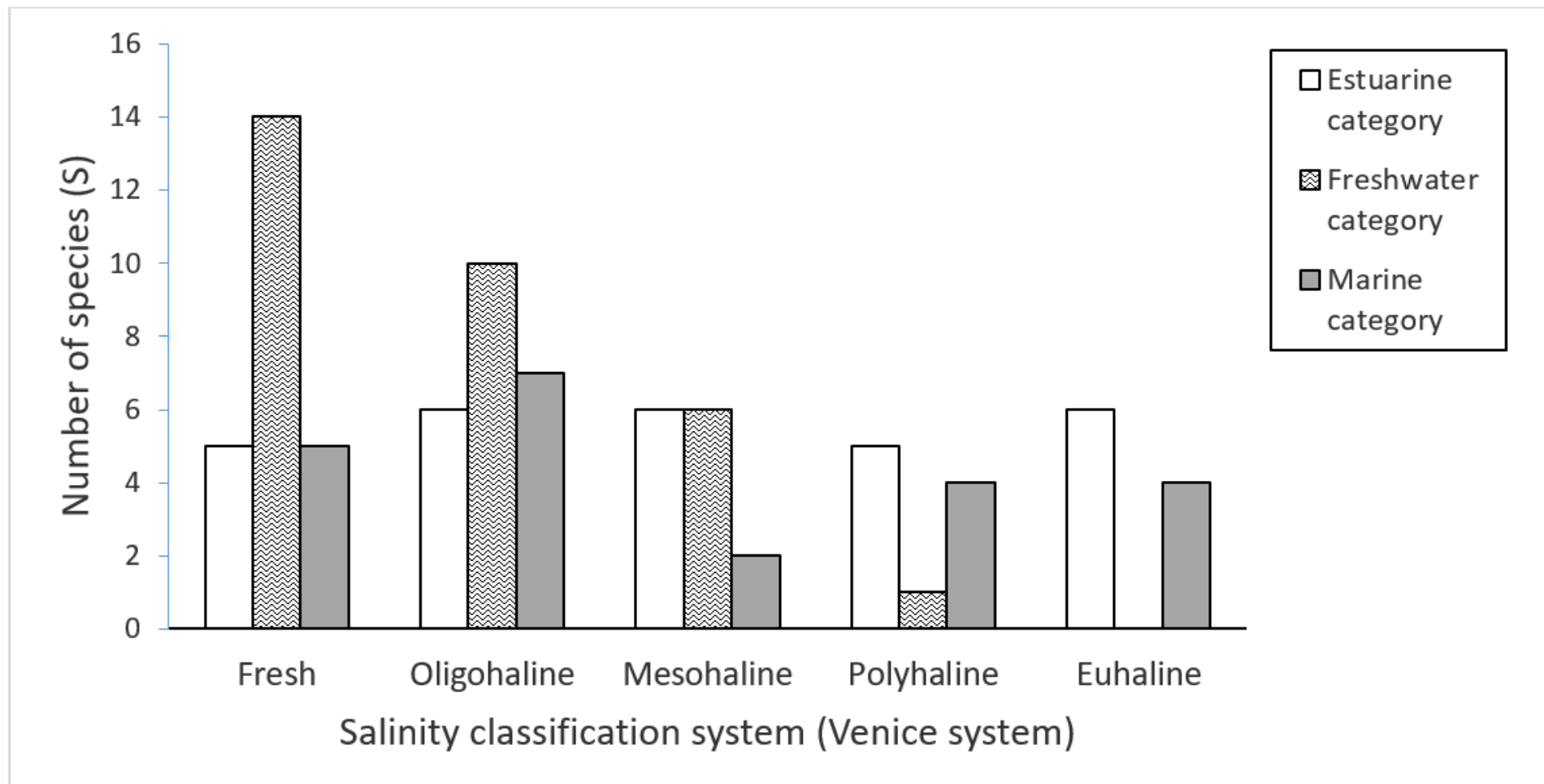

\section{Figure 3}

Trends in the number of species recorded during the entire study period 2004 - 2018, in the Orange River Estuary, showing changes in fish association along the salinity continuum based on an adaptation of the Venice system for the classification of South African salinity zones in estuaries (Strydom et al. 2003). 